\title{
Toxicity assessment of residual biomass of microalgae Chlorella sorokiniana
}

\author{
(C) Yulia A. Smyatskaya \\ Civil Engineering Institute. Peter the Great St. Petersburg Polytechnic University. Polytechnicheskaya St., 29. \\ St. Petersburg, 194064. Russia. Phone: +7 9218686554.E-mail: Makarovayulia169@mail.ru
}

Keywords: microalgae, toxicity, residual biomass, crustaceans Daphnia magna Straus.

\begin{abstract}
In this paper, the determination of the toxicity of residual biomass of microalgae Chlorella sorokiniana by the method of biotesting with use of the test - object Daphnia magna Straus and algae Chlorella vulgaris Beijer. Determination of the toxic effect is necessary for planning the possibility of further use of waste, as a sorption material for wastewater treatment, as a co-substrate for fermentation of organic waste and in the
\end{abstract} production of biogas.

The residual biomass of Chlorella sorokiniana microalgae is formed after the extraction of valuable components (lipid complex, pigments, proteins, etc.).

The extraction of the lipid complex uses organic solvents (hexane, ethyl alcohol), the remains of which can remain in the residual biomass. Determined the acute toxicity of residual biomass of microalgae by water extraction with the help of test-object Daphnia magna Straus and the test object microalgae Chlorella vulgaris Beijer according to standard methods. According to the study waste source of residual biomass to treat the IV class of hazard, $\mathrm{LDR}_{50-48}$ (lethal dilution ratio) $=11.7 ; \mathrm{SDR}_{10^{-48}}$ (safe dilution ratio) $=35.48$. To reduce the toxic effect is proposed to conduct heat treatment. Heat treatment was carried out in a muffle furnace at a temperature of $105^{\circ} \mathrm{C}$ for 1 hour.

Experimental studies using Daphnia magna Straus crustaceans showed that the value of A is $3 \%$, which indicates the absence of toxicity of residual biomass. When using microalgae toxicity criterion was also not exceeded in any dilution of water, including its original undiluted version.

It is established that after heat treatment the residual biomass of microalgae becomes non-toxic and has a $\mathrm{V}$ hazard class. The results indicate the possibility of re-use of residual biomass.

\section{References}

[1] E.T. Yamansarova, N.V. Gromyko, M.I. Abdullin O.S. Kukinetsy, O.B. Zvorygina. Investigation of the sorption properties of materials based on plant materials in relation to oil pollution of water. Bulletin of Bashkir University. 2015. Vo.20. No.4. P.1209-1212. (russian)

[2] Daniela Suteu, Carmen Zaharia, Marinela Badeanu Agriculture wastes used as sorbents for dyes removal from aqueous environments. Lucrări Ştiinţifice. Seria Agronomie. 2010. Vol.53. No.1. P.140-145.

[3] Meenakshi Nandal, Rajni Hooda and Geeta Dhania Tea Wastes as a Sorbent for Removal of Heavy Metals from wastewater. International Journal of Current Engineering and Technology. 2014. Vol.4. No.1. P.243-247.

[4] A. Naga Babu, D. Srinivasa Reddy, G. Suresh Kumar, K. Ravindhranath, G.V. Krishna Mohan Removal of lead and fluoride from contaminated water using exhausted coffee grounds based bio-sorbent. Journal of Environmental Management. 2018. Vol.208. P.602-612.

[5] N.G. Gabruk, I.I. Oleynikova, T.A. Shuteeva, D.E. Smalchenko Obtaining, activating and modifying carbon material from walnut shells. Scientific Gazette. Science Series. 2013. No.7(160). Iss.24. P.114116. (russian)

[6] A.Sh. Shaymardanova, S.V. Stepanova. The use of leaf litter as a sorption material in relation to iron ions. Research publications: nature, ecology and national economy. 2015. Vol.1. No.2(22). (russian)

[7] Adsorption treatment of industrial sewage by modified carbonate slime: PhD Thesis of the doctor of technical sciences: 03.02.08. Nikolaeva Larisa Andreevna; [Place of defense: Ivan. state chemicaltehnol. un-t]. Kazan. 2016. 267p.

[8] A. A. Protsenko, A.E. Kuznetsov, E.P. Protsenko, I.P. Balabina, N.V. Ermakova, M.V. Protasova, O.V. Lukyanchikova. Problems of toxicity pulp waste beet-sugar production. Problems of regional ecology. 2015. No.2. P.86-89. (russian) 
TOXICITY ASSESSMENT OF RESIDUAL BIOMASS OF MICROALGAE CHLORELLA SOROKINIANA

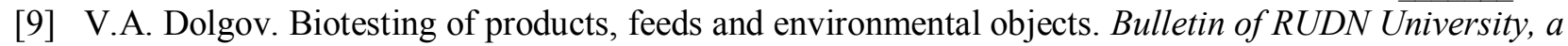
series of Agronomy and animal husbandry. 2014. No.3. P.69-79. (russian)

[10] N.A. Politaeva, T.A. Kuznetsova, Y.A. Smyatskaya, E.V. Trukhina, I. Atamanyuk. Energy Production from Chlorella Algae Biomass Under St. Petersburg Climatic Conditions. Chemical and Petroleum Engineering. 2018. Vol.53. No.11-12. P.801-805.

[11] N. Politaeva, T. Kuznetsova, Y. Smyatskaya, I. Atamaniuk, E. Trukhina. Chlorella Microalga Biomass Cultivation for Obtaining Energy in Climatic Conditions of St. Petersburg. Advances in Intelligent Systems and Computing. 2018. Vol.692. P.555-562.

[12] Yu.A. Smyatskaya, N.A. Politaeva, V.S. Sobgaida. Photobioreactors for the cultivation of microalgae Chlorella sorokiniana. Bulletin of the Technological University. 2018. Vol.21. No.2. P.224-227. (russian) 